\title{
Identifikasi Pusat Pertumbuhan dan Analisis Interaksi Spasial Perekonomian di Provinsi Jawa Timur
}

\author{
Irhas Fudhail $^{1}$, Herman Sambodo ${ }^{2 *}$, Sodik Dwi Purnomo ${ }^{3}$ \\ ${ }^{1,2}$ Fakultas Ekonomi dan Bisnis, Universitas Jenderal Soedirman, Purwokerto \\ ${ }^{3}$ Fakultas Ekonomika dan Bisnis, Universitas Wijayakusuma, Purwokerto \\ *Coresponding email: herman.sambodo@unsoed.ac.id
}

\begin{abstract}
Abstrak. Provinsi Jawa Timur merupakan satu diantara wilayah terluas dan memiliki PDRB tertinggi kedua di Pulau Jawa. Namun, berdasarkan indeks Williamson tingkat distribusi pendapatan antar wilayah kabupaten/kota dalam provinsi tersebut masih rendah. Penelitian ini bertujuan menganalisis pusat-pusat pertumbuhan dan interaksi spasial wilayah kabupaten/kota di Provinsi Jawa Timur tahun 2009 dan 2018. Metode penlitian menggunakan analisis model gravitasi dan analisis skalogram. Hasil analisis skalogram dan indeks sentralitas menunjukkan tahun 2009 terdapat 3 kabupaten/kota yag termasuk dalam Hirarki I, 5 kabupaten/kota pada Hirarki II, 6 kabupaten/kota pada Hirarki III, 9 kabupaten/kota pada Hirarki IV, 12 kabupaten/kota pada Hirarki V dan 3 kabupaten/kota VI. Pada tahun 2018 terdapat 8 kabupaten/kota pada Hirarki I, 10 kabupaten/kota pada Hirarki II, 11 kabupaten/kota pada Hirarki III, 4 kabupaten/kota pada Hirarki IV, 3 kabupaten/kota pada Hirarki V dan 2 kabupaten/kota pada Hirarki VI. Pusat pertumbuhan dengan daerah hinterlandnya pada tahun 2009 ke 2018 mengalami kenaikan. Dari tahun 2009 ke tahun 2018 daerah hinterland yang berinteraksi kuat dengan Kota Surabaya seperti Kabupaten Sidoarjo, Gresik dan Bangkalan. Implikasi kebijakan perlunya peningkatan kerja sama antar wilayah baik dalam bidang ekonomi maupun sosial antara wilayah yang menjadi pusat pertumbuhan dengan wilayah hinterlandnya.
\end{abstract}

Kata Kunci: Pusat Pertumbuhan Ekonomi, Skalogram, Model Gravitasi

\begin{abstract}
East Java Province is one of the largest regions and has the second highest GDP on Java Island. However, based on the Williamson index the level of income distribution within regions districts/cities is still low. This study intent to analyze areas that become growth pole and spatial economic interactions in East Java Province in 2009 and 2018. The analyses used in this research are gravity model analysis and scalogram analysis. The results of scalogram analysis and centrality showed that in 2009 there were 3 districts/cities included in Hierarchy I, 5 districts/cities in Hierarchy II, 6 districts/cities in Hierarchy III, 9 districts/cities in Hierarchy IV, 12 districts/cities in Hierarchy V and 3 districts/cities VI. While in 2018 there were 8 districts/cities in Hierarchy I, 10 districts/cities in Hierarchy II, 11 districts/cities in Hierarchy III, 4 districts/cities in Hierarchy $I V, 3$ districts/cities in Hierarchy V and 2 districts/cities in Hierarchy VI. Growth pole areas within hinterland areas in 2009 to 2018 increased. From 2009 to 2018 hinterland areas that interact strongly with the city of Surabaya such as Sidoarjo Regency, Gresik Regency and Bangkalan Regency. The results imply the necessity to increase interaction or cooperation both in the economic and social between the regions which are the center of growth and the hinterland region such as in the economic sector.
\end{abstract}

Keywords: Center for Economic Growth, Scalogram, Gravity Model

\section{Pendahuluan}

Pertumbuhan ekonomi ialah satu diantara indikator yang menilai kesuksesan pembangunan ekonomi sebuah negara. Hakim (2009) menyatakan pokok dari pembangunan ekonomi ialah terdapatnya pertumbuhan ekonomi. Menurut Pratiwi dan Kuncoro (2016) pembangunan tak cuma diperlihatkan oleh prestasi pertumbuhan ekonomi yang digapai, tetapi melebihi itu, karena pembangunan mempunyai perspektif yang luas. Pertumbuhan ekonomi yang dicitakan setiap negara yakni pertumbuhan yang berkelanjutan, idealnya pertumbuhan ekonomi mampu mewujudkan kesejahteraan secara merata pada seluruh wilayah dalam suatu negara. Menurut Kuncoro (2004) berlangsungnya kemajuan di pembangunan ekonomi suatu daerah satu diantara indikatornya juga tercermin dalam pertumbuhan ekonomi yang digapai daerah itu. Pertumbuhan ekonomi ini dipengaruhi oleh beragam aspek. Tidak hanya resource endowment (sumberdaya alam yang dipunya sebuah daerah), keunggulan demografis, performa perekonomian daerah, namun aspek spasial (kewilayahan) ikut mempengaruhi pula. Perbedaan-perbedaan pada faktor yang mempengaruhi pertumbuhan ekonomi tersebut mengakibatkan perbedaan di pembangunan antar wilayah atau kesenjangan pembangunan antar wilayah.

Salah satu kebijakan pemerintah dalam meningkatkan pembangunan dan pertumbuhan ekonomi yaitu lewat pengembangan wilayah. Pengembangan wilayah ialah usaha pembangunan guna meratakan pertumbuhan wilayah serta menurunkan kesenjangan antar wilayah bersama memakai beragam sumber daya alam (SDA), manusia, kelembagaan, teknologi serta prasarana fisik secara efektif, optimal, serta berkelanjutan. Strategi pembangunan pengembangan wilayah dapat dilakukan dengan menetapkan kota atau wilayah tertentu menjadi pusat-pusat pertumbuhan (growth pole). Pusat pertumbuhan ialah satu diantara cara guna menggerakan serta menstimulasi pembangunan untuk menaikkan kesejahteraan rakyat (Tarigan (2006). Berkaitan dengan pusat pertumbuhan (growth 
pole), Perroux (1955) dalam Tarigan (2006) berpendapat bahwa pembangunan ekonomi dalam suatu daerah tidak terjadi secara merata pada waktu yang bersamaan di berbagai daerah, tetapi berkecondongan untuk mengelompok pada pusat-pusat pertumbuhan pertumbuhan dengan intensitas yang beda serta sebab yang berbeda Pada konteks yang sepadan Sukirno (2001) menjabarkan pusat pertumbuhan itu hendak menetapkan perkembangan wilayah lain. Model pengembangan pusat-pusat pertumbuhan tersebut diharapkan dapat menimbulkan spread effect (efek sebar) dari aktivitas pusat pertumbuhan, hingga wilayah sekitar mampu bertumbuh. Dengan demikian kesuksesan pertumbuhan ekonomi sebuah wilayah tak bisa dianggap selaku kesuksesan wilayah tersebut, tetapi banyak dipengaruhi oleh perkembangan daerah disekitarnya. Menurut Dobrescu \& Dobre (2014), pusat pertumbuhan akan melimpah ke daerah sekitarnya dan turut berpartisipasi di proses pertumbuhan ekonomi wilayah sekitar. Pusat pertumbuhan ekonomi adalah wilayah perkotaan ataupun perindustrian yang manjadi konsentrasi pertumbuhan dan memiliki hubungan bersama industri ataupun wilayah lainnya.

Perroux dalam Tarigan (2006) juga mengartikan pusat pertumbuhan bersama 2 macam cara, yakni secara fungsional serta geografis. Secara fungsional pusat pertumbuhan ialah suatu tempat konsentrasi atau pengelompokan golongan usaha yang sebab sifat korelasinya mempunyai elemen kedinamisan, hingga pada akhirnya dapat menjadi pemicu kehidupan ekonomi ke dalam ataupun ke luar (hinterland-nya). Jika ditinjau secara geografis, pusat pertumbuhan ialah sebuah tempat yang mempunyai berlimpah fasilitas serta kegampangan, hingga jadi pusat daya tarik (pole of attraction) yang mengakibatkan beragam usaha tertarik guna bertempat dikawasan itu. Model pembangunan pusat-pusat pertumbuhan ini, tidak bisa terlepas dari interaksi spasial antar wilayah. Hubungan baku terpaut atau interaksi spasial antar wilayah inilah yang akan mempengaruhi keberhasilan model pusat pertumbuhan, tanpa interaksi antara pusat pertumbuhan dan wilayah sekitarnya maka tidak akan berdampak pada pembangunan daerah sekitarnya (Capello, 2009). Dua atau lebih wilayah yang saling berdekatan, walaupun sebelumnya merupakan wilayah yang berdiri sendiri dan independen, dapat menerima keuntungan berupa sinergi dari pertumbuhan wilayah yang interaktif apabila terjadi interaksi spasial (Batten, 1995 dalam Kuncoro, 2012). Daerah-daerah yang berdekatan satu sama lain akan memiliki keterkaitan dan interaksi yang lebih kuat dibanding daerah yang saling berjauhan (Hukum Tobler I). Maka dari itu diperlukan koordinasi yang baik dan perlu diimplementasikan suatu bentuk kebijakan pembangunan spasial, sehingga interaksi spasial menjadi sinergi yang bisa menimbulkan kemajuan secara beriringan.

Penetapan pusat pertumbuhan di suatu daerah mempunyai kedudukan yang amat esensial guna menetapkan arah kebijakan serta regulasi untuk pemerintah pusat ataupun daerah guna melaksanakan pembangunan wilayah. Penetapan pusat pertumbuhan memiliki kegunaan guna meratakan pembangunan di seluruh wilayah, memudahkan koordinasi antar wilayah serta mengoptimumkan pengontrolan potensi serta SDA yang ada. Hirschman (dalam Adisasmita, 2005) menjelaskan bahwa pertumbuhan ekonomi pada daerah pusat pertumbuhan hendak berdampak terhadap daerah hinterlandnya lewat efek polarisasi (polarization effect), efek penetesan kebawah (trickling down effect) serta mendorong sebuah daerah berkembang jadi pusat pertumbuhan. Oleh karena itu penetapan pusat pertumbuhan di suatu wilayah amat esensial dilaksanakan.

Provinsi Jawa Timur merupakan satu diantara dari provinsi dengan daerah terluas di Pulau Jawa, yaitu $47.799,75 \mathrm{Km}^{2}$. Dengan kondisi wilayah yang luas diperlukan usaha yang besar untuk menciptakan pembangunan ekonomi yang merata diseluruh wilayah. Sesuai data Badan Pusat Statistik (BPS) tahun 2019, besarnya perolehan PDRB Provinsi Jawa Timur tahun 2018 termasuk tinggi diantara provinsi-provinsi di Pulau Jawa. Secara lebih rinci perbandingan PDRB di Pulau Jawa disajikan pada Gambar 1.

Gambar 1.

Produk Domestik Regional Bruto (PDRB) Berdasarkan Harga Konstan Tahun 2010 Provinsi di Pulau Jawa Tahun 2018 (Miliar Rupiah)

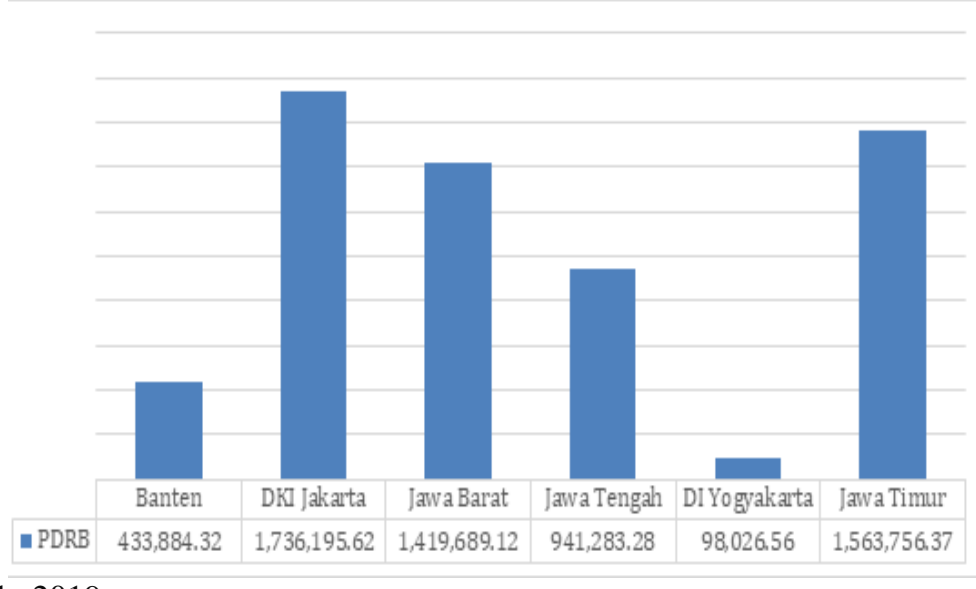

Sumber : Badan Pusat Statistik, 2019 
Pada tahun 2018 Provinsi Jawa Timur menempati urutan kedua dengan jumlah PDRB sebesar 1.563.756,37 miliar rupiah. Meskipun angka PDRB nya cukup tinggi namun, pemeratan pendapatan antar wilayahnya dapat dikatakan cukup rendah apabila dibanding provinsi-provinsi lain di Pulau Jawa. Hal ini ditunjukkan oleh taraf ketimpangan pendapatan masyarakat di Provinsi Jawa Timur yang cukup tinggi. Gambar 2 menunjukkan perbandingan nilai indeks Williamsons provinsi di Pulau Jawa Tahun 2018, dimana indeks Wiliamson menunjukkan nilai ketimpangan pendapatan antar wilayah atau daerah (Sjafrizal, 2008).

\section{Gambar 2.}

\section{Perbandingan Indeks Williamson antar Provinsi di Pulau Jawa Tahun 2018}

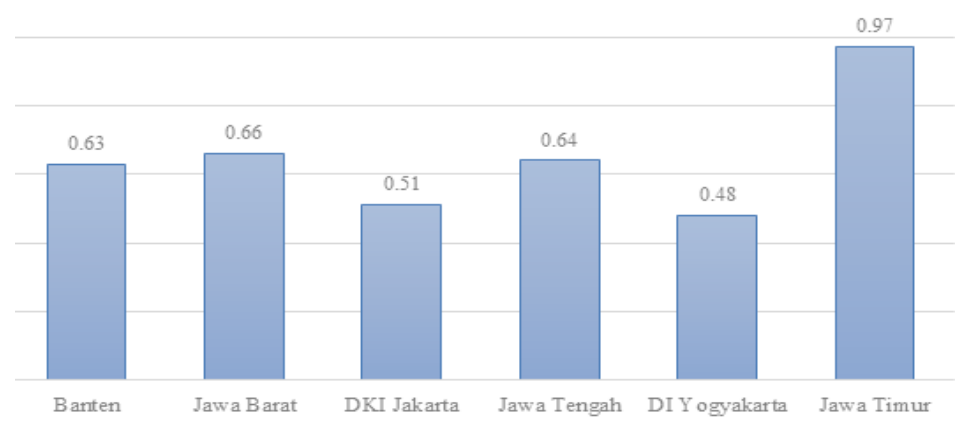

Sumber : Badan Pusat Statistik, Diolah 2019

Gambar 2 menunjukkan bahwa indeks Wiliamson Provinsi Jawa Timur bernilai paling tinggi yakni 0,97. Nilai ini menjelaskan tingkat distribusi pendapatan antar wilayah dalam konteks ini yaitu kabupaten/kota sangat rendah, atau dengan kata lain terjadi ketimpangan pendapatan antar wilayah yang tinggi. Namun, ketimpangan antar wilayah tersebut berbanding terbalik dengan ketimpangan pendapatan antar penduduk, ini terlihat dari indeks gini Provinsi Jawa Timur yang sebesar 0,37 . Menurut nilainya, nilai indeks gini tersebut menunjukkan bahwa pendapatan masyarakat termasuk merata secara umum. Gambar 3 menunjukkan perbandingan nilai indeks gini provinsi di Pulau Jawa.

Gambar 3.

Perbandingan Indeks Gini Provinsi-Provinsi di Pulau Jawa Tahun 2018

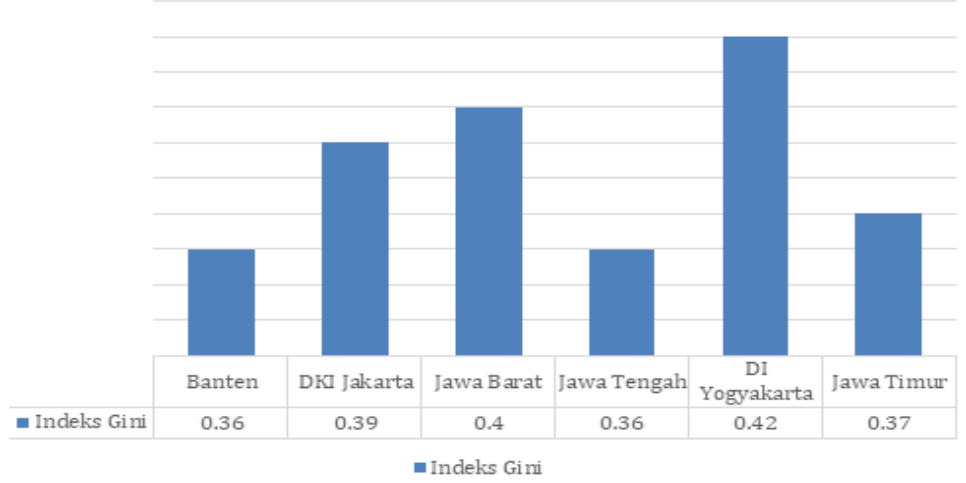

Sumber : Badan Pusat Statistik, Diolah

Berdasarkan kondisi riil di Provinsi Jawa Timur tingkat pemeratan tingkat pembangunan ekonomi daerah masih cukup rendah (merata). Atas dasar hal tersebut, maka studi ini bermaksud guna mengidentifikasi kabupaten/kota mana yang berperan selaku pusat pertumbuhan yang menopang perumbuhan ekonomi daerah secara umum. Selain itu, penelitian ini akan mengidentifikasi kabupaten/kota di Provinsi Jawa Timur yang mempunyai potensi dan layak selaku pusat pertumbuhan baru. Selanjutnya, akan dilakuan analisis terkait interaksi spasial ekonomi antara daerah sebagai pusat-pusat pertumbuhan dengan daerah-daerah belakangnya.

Penelitian serupa juga telah dilakukan oleh beberapa peneliti sebelumnya. Priyadi dan Atmadja (2017) mengidentifikasi pusat-pusat pertumbuhan dan wilayah hinterland di Provinsi Yogyakarta, menggunakan metode analisis konsentrasi geografi, analisis skalogam dan analisis gravitasi. Pratiwi dan Kuncoro (2016) dengan melaksanakan analisis pusat perumbuhan serta autokorelasi spasial di Kalimantan, dengan tujuan untuk mengidentifikasi kabupaten/kota di Pulau Kalimantan yang hendak jadi pusat pertumbuhan serta apa ada autokorelasi spasial antar provinsi di Pulau Kalimantan. Menggunakan metode analisis tipologi kabupaten/kota, autokorelasi 
spasial, analisis overlay serta transformasi struktural, capaian studi memperlihatkan bahwa ada empat kota selaku pusat pertumbuhan bersama konsentrasi pertumbuhan ekonomi tersebar diwilayah timur serta barat Pulau Kalimantan. Penelitian Kubis et al. (2007) menemukan bahwa menemukan terdapat 20 pusat pertumbuhan dan semuanya terdapat diwilayah bagian timur Jerman yang merupakan daerah industri. Funke dan Annekatrin (2005) juga melakukan penelitian serupa di Jerman. Ditemukan bahwa setiap daerah memiliki keterkaitan satu sama lain serta mendapatkan keuntungan dari daerah yang menjadi pusat pertumbuhan. Selain itu, temuan Ke \& Feser (2010) menemukan bahhwa kota-kota besar yang menjadi pusat pertumbuhan diwilayah Cina bagian tengah dapat membantu kota-kota kecil dan wilayah sekitarnya yang tertinggal.

Melihat kondisi perekonomian Indonesia yang terus mengalami perubahan, maka peneliti merasa perlu untuk dilakukan penelitian terkait kondisi regionalisasi daerah di Provinsi Jawa Timur. Sehingga hal yang melatarbelakangi studi ini yakni; Provinsi Jawa Timur ialah satu diantara wilayah dengan wilayah terluas di Pulau Jawa serta mempunyai PDRB tertinggi kedua di Pulau Jawa. Namun, berdasarkan indeks Williamson tingkat distribusi pendapatan antar wilayah antar kabupaten/kota sangat rendah, atau terjadi ketimpangan pendapatan antar wilayah yang tinggi. Selain ketimpangan pendapatan antar wilayah, ketimpangan pendapatan masyarakat juga cukup tinggi. Dengan kondisi wilayah yang cukup luas tersebut perlu ditetapkan adanya wilayah sebagai pusat pertumbuhan, agar terbentuk pemerataan pembangunan antar wilayah.

\section{Metode}

Penelitian ini merupakan penelitian deskriptif kuantitatif. Secara deskriptif, penelitian ini akan menelaah seberapa kuat interaksi spasial ekonomi yang timbul antara daerah pusat-pusat pertumbuhan di Jawa Timur dengan daerah-daearah lain di Jawa Timur lainnya, sehingga dapat mempengaruhi pertumbuhan ekonomi provinsi Jawa Timur. Secara kuantitatif, penelitian ini akan menerka data yang ada untuk mengamati bagaimana dampak interaksi spasial ekonomi terhadap pertumbuhan ekonomi. Penelitian ini menggunakan data sekunder, dimana kelengkapan data tersebut berbentuk panel data yang terdiri dari periode tahun 2009 dan 2018 dan cross section data (data kerat silang) dari 38 Kabupaten/Kota di Jawa Timur. Data yang dipakai melingkupi fasilitas/infrastruktur publik, populasi atau jumlah penduduk, jarak antar daerah di kabupaten/kota Provinsi Jawa Timur.

Semakin tinggi perkembangan sebuah wilayah bermakna wilayah itu semakin dapat memberi pelayanan pada warganya. Pelayanan yang diartikan perihal ini ialah adanya fasilitas diwilayah tersebut misalnya fasilitas yang berhubungan bersama kegiatan ekonomi, kegiatan sosial serta pemerintah. Pada studi ini jumlah seluruh fasilitas yang dipakai ialah 29 macam fasilitas. Macam fasilitas yang dipakai di studi ini ada 29 fasilitas, yakni (1) taman kanakkanak (TK), (2) sekolah dasar (SD)/sederajat, (3) sekolah menengah pertama (SMP)/sederajat, (4) sekolah menengah atas (SMA)/sederajat, (5) perguruan tinggi (PT), (6) sekolah luar biasa (SLB), (7) rumah sakit, (8) rumah bersalin, (9) puskesmas, (10) puskesmas pembantu, (11) posyandu, (12) pasar, (13) restoran, (14) swalayan/toserba, (15) minimarket, (16) toko/warung kelontong, (17) industri, (18) bank umum, (19) bank swasta, (20) bank perkreditan rakyat (BPR), (21) kospin, (22) hotel, (23) internet kantor desa, (24) kantor pos, (25) masjid, (26) gereja kristen, (27) gereja katolik, (28) pura serta (29) polsek.

Alat analisis yang dipakai di studi ini yakni model skalogram. Skalogram ialah alat analisis guna mengidentifikasi pusat pertumbuhan wilayah sesuai fasilitas yang dipunya, hingga mampu ditetapkan hierarki pusatpusat pertumbuhan serta kegiatan pelayanan sebuah wilayah. Metode skalogram ialah metode paling sederhana yang mampu dipakai guna melaksanakan analisis fungsi wilayah, sebab cuma memperlihatkan daftar dari bagian pendukungnya (Riyadi, 2008). Tahap penyusunan analisis skalogram sesuai Rondinelli dan Budiharsono dalam Mulyadi (2007) yakni:

1) Menciptakan urutan kota sesuai total penduduk di sebelah kiri tabel,

2) Menciptakan urutan fasilitas yang ditetapkan sesuai frekuensi di bagian atas,

3) Menggambarkan garis kolom serta baris hingga lembar kerja itu membentuk matriks yang menyajikan fasilitas yang terdapat di tiap wilayah kota,

4) Memakai tanda (1) di sel yang menjabarkan keberadaan sebuah fasilitas di sebuah wilayah serta tanda (0) pada sel yang tak mempunyai fasilitas,

5) Menderetkan ulang baris serta kolom sesuai frekuensi keberadaan fasilitas, kian banyak fasilitas yang terdapat di sebuah wilayah kota, hingga wilayah itu ada di urutan atas, kian banyak wilayah yang mempunyai fasilitas itu, maka macam fasilitas itu ada di kolom sebelah kiri,

6) Mengalikan kolom-kolom yang sudah disusun bersama nilai indeks sentralitas masing-masing lalu dirancang ulang seperti langkah lima,

7) Langkah terakhir yakni menandai peringkat/hirarki kota yang mampu diasosiasikan sesuai nilai keberadaan fasilitas di sebuah wilayah. Kian tinggi nilainya, maka hirarki kota itu hendak kian tinggi

Lalu, Indeks sentralitas (Centrality Indeks Analysis) ialah langkah lanjutan dari analisis skalogram yang di analisisnya tak cuma sesuai total fungsi ataupun fasilitas pelayanan yang terdapat di sebuah wilayah, namun sesuai 
pula frekuensi keberadaan fungsi ataupun fasilitas itu di wilayah yang dilihat. Frekuensi keberadaan fungsi memperlihatkan total fungsi semacam yang ada serta tersebar di wilayah tertentu (Mutaali, 2003) dengan rumus

$\mathrm{C}=(\mathrm{x} / \mathrm{X})$

Dimana : $C=$ bobot atribut fungsi $\mathrm{x} ; \mathrm{X}=$ jumlah total fungsi dalam system; $\mathrm{x}=$ Nilai sentralitas gabungan $=100$

Menurut Hayness dan Fotheringham (1984) yang dikulip dari Irsyad (2018), model gravitasi ialah model yang paling umum dipakai guna menguraikan interaksi spasial. Bersama model ini mampu diketahui pengaruh dari wilayah yang satu bersama lainnya. Data yang dipakai ialah total penduduk wilayah asal (Pi), total penduduk wilayah tujuan (Pj) serta jarak wilayah asal ke wilayah tujuan (dij). Tahap model gravitasi dirumuskan yakni:

Angka Interaksi $(A i j)=k \frac{P_{i} \times P_{j}}{d_{i j}}$

Dimana $: k \quad=$ konstanta rerata perjalanan per penduduk; $P_{i}=$ Penduduk kabupaten I; $P_{j}=$ Penduduk kabupaten j; $d_{i j} \quad=$ Jarak antara i serta $\mathrm{j}$

Pemakaian model ini guna mengatahui daya tarik sebuah potensi di sebuah tempat. Kian jauh jarak antara dua lokasi hingga kian menurun ketertarikan dari individu guna bepergian ke lokasi lainnya. Variabel yang dipakai di model ini menggunakan total penduduk serta jarak antar wilayah (Tarigan, 2006). Model gravitasi dipakai guna mencari tahu bagaimanakah interaksi antara pusat pertumbuhan bersama wilayah hinterland nya. Kian besar angka interaksi yang didapat sebuah wilayah hingga kian erat hubungan wilayah itu bersama wilayah lain. Perihal ini bermakna kian potensial daerah itu guna berkembang sebab keterkaitan antar aktivitas ekonominya erat.

\section{Hasil}

\section{Pusat-Pusat Pertumbuhan Ekonomi di Provinsi Jawa}

Analisis skalogram merupakan instrumen analisis yang berfungsi untuk menentukan pusat pertumbuhan pada suatu kawasan. Blakely (1994) menuturkan bahwa analisis skalogram dimanfaatkan untuk mengamati fasilitas perkotaan yang dimiliki sebagai penanda suatu kawasan menjadi pusat pertumbuhan. Penelitian ini menggunakan 29 fasilitas publik meliputi (1) taman kanak-kanak (TK), (2) sekolah dasar (SD)/sederajat, (3) sekolah menengah pertama (SMP)/sederajat, (4) sekolah menengah atas (SMA)/sederajat, (5) perguruan tinggi (PT), (6) sekolah luar biasa (SLB), (7) rumah sakit, (8) rumah bersalin, (9) puskesmas, (10) puskesmas pembantu, (11) posyandu, (12) pasar, (13) restoran, (14) swalayan/toserba, (15) minimarket, (16) toko/warung kelontong, (17) industri, (18) bank umum, (19) bank swasta, (20) bank perkreditan rakyat (BPR), (21) kospin, (22) hotel, (23) internet kantor desa, (24) kantor pos, (25) masjid, (26) gereja kristen, (27) gereja katolik, (28) pura serta (29) polsek.. Berdasarkan hasil analisis skalogram didapatkan hasil perhitungan pusat pertumbuhan, sehingga dapat digambarkan dalam peta. Hasil analisis skalogram di Provinsi Jawa Timur pada tahun 2009 dan 2018 menunjukkan perubahan jumlah pusat pertumbuhan.

\section{Gambar 4.}

Peta Pusat Pertumbuhan Ekonomi di Provinsi Jawa Timur Pada Tahun 2009
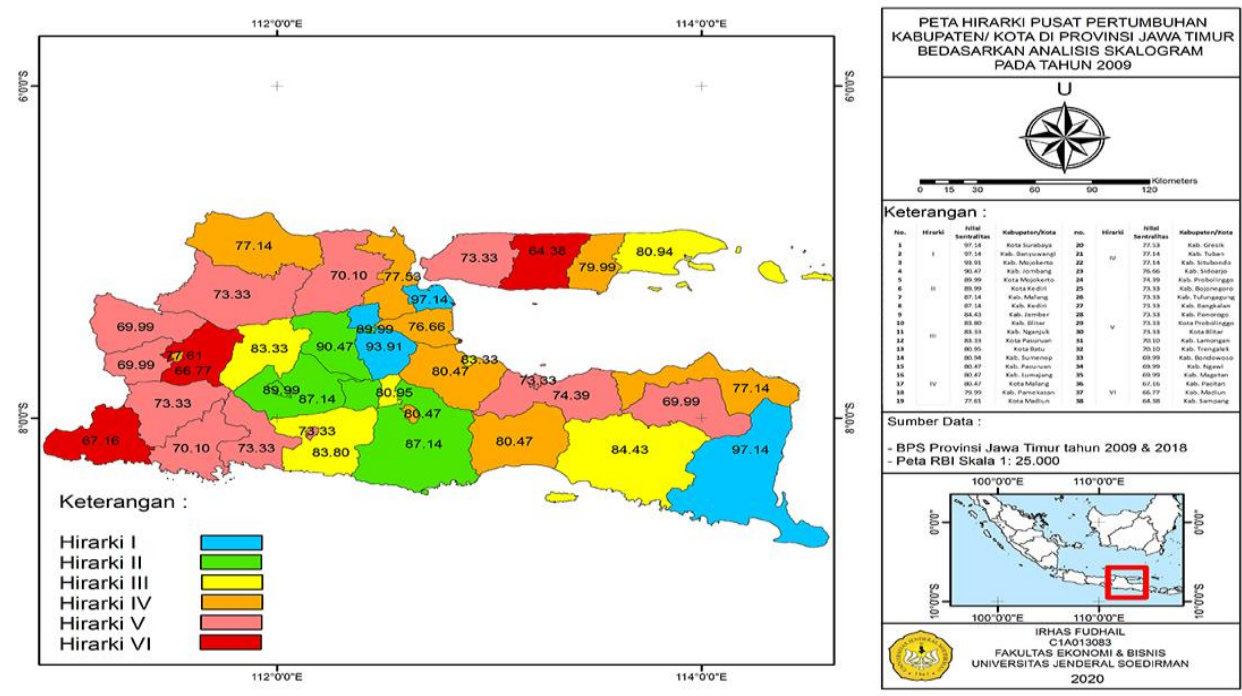

Sumber: Data BPS diolah 2020

Gambar 4 memperlihatkan bahwa pusat pertumbuhan ekonomi pada tahun 2009 di Provinsi Jawa Timur yang menggunakan rumus skalogram terbagi menjadi 6 herarki pusat pertumbuhan. Herarki I menunjukkan pusat pertumbuhan ekonomi tertinggi yang terdiri dari 3 kabupaten/kota. Pada Herarki II terdapat 5 kabupaten/kota, Hirearki 
III terdapat 6 kabupaten/kota, Hirarki IV terdapat 9 Kabupaten/kota, Hirarki V terdapat 12 kabupaten/kota, dan di Hirarkei VI terdapat 3 kabupaten/kota. Pada tahun 2009 pusat pertumbuhan tertinggi di Provinsi Jawa Timur hanya didominasi oleh 3 daerah saja yaitu Kota Surabaya, Kabupaten Banyuwangi, dan Kabupaten Mojokerto. Selain itu, masih banyak kabupaten/kota di Hirarki IV dan V yang menunjukkan pertumbuhan ekonomi yang tergolong rendah. Sementara itu, daerah yang menjadi pusat pertumbuhan terendah atau yang berada di Hirarki VI adalah Kabupaten Pacitan, Kabupaten Sampang, dan Kabupaten Madiun.

Selanjutnya hasil perhitungan pusat pertumbuhan ekonomi di Provinsi Jawa timur tahun 2009 dibandingkan dengan tahun 2018. Hal tersebut didasarkan apakah ada perubahan yang menjadi pusat pertumbuhan perumbuhan ekonomi di Provinsi Jawa Timur. Berikut Gambar 5 yang menunjukkan pusat-pusat pertumbuhan ekonomi di Provinsi Jawa Timur pada tahun 2018.

\section{Gambar 5.}

Peta Pusat Pertumbuhan Ekonomi di Provinsi Jawa Timur Pada Tahun 2018
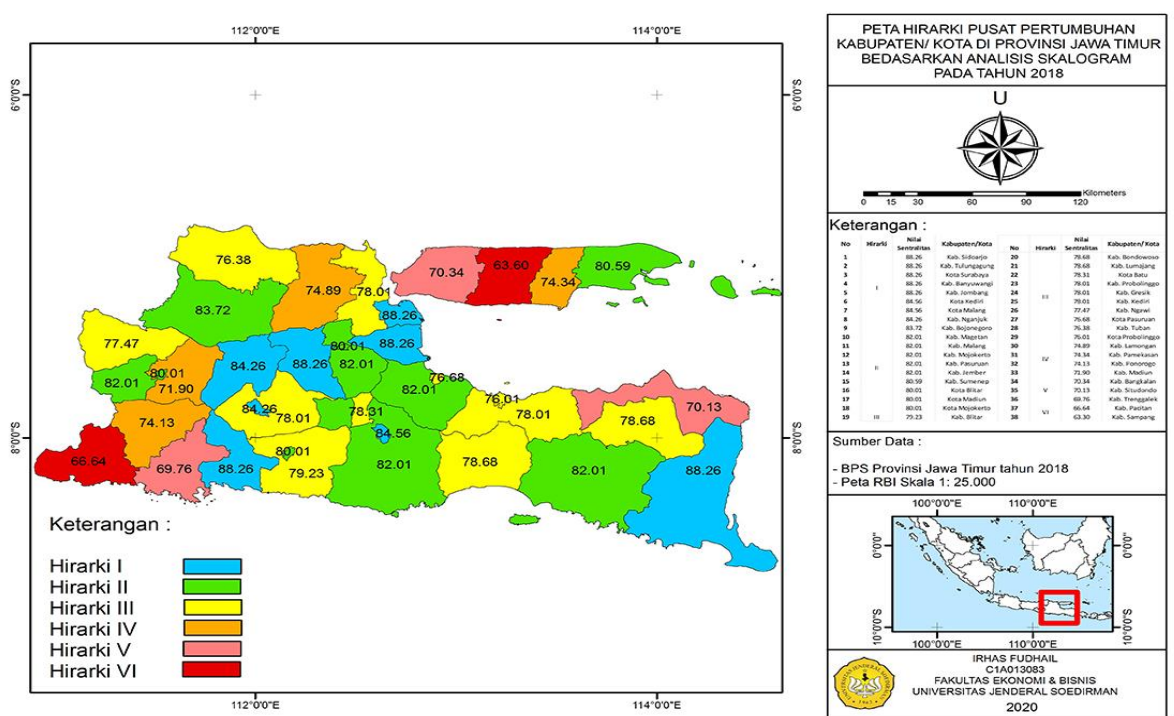

Sumber: Data BPS dioalah 2020

Gambar 5 menunjukkan terdapat 6 hirarki pusat pertumbuhan ekonomi di Provinsi Jawa Timur. Jika dibandingkan dengan tahun 2009 terdapat perbedaan pusat pertumbuhan di setiap hirarkinya. Pada Hirarki I tahun 2018 terdapat 8 kabupaten/kota yang menjadi pusat pertumbuhan ekonomi lebih banyak jida dibandingkan dengan 2009 yang hanya memiliki 3 kabupaten/kota. Pada tahun 2018 di Hirarki II terdapat 10 kabupaten/kota lebih banyak jika dibandingkan tahun 2009 pada Hererki II yang terdapat 5 kabupaten kota. Pada tahun 2018 hirarki III terdapat 10 kabupaten/kota lebih sedikit jika dibandingkan tahun 2009 pada Hirarki III terdapat 6 kabupaten/kota. Pada tahun 2018 Hirarki IV terdapat 4 kabupaten/kota lebih sedikit jika bibandingkan tahun 2009 di Hirarki V yang terdapat 9 kabupaten/kota. Pada Tahun 2018 Hirarki V terdapat 3 kabupaten/kota lebih sedikit jika bibandingkan tahun 2009 di Hirarki V yang terdapat 12 kabupaten/kota. Pada Tahun 2018 Hirarki VI terdapat 1 kabupaten/kota lebih sedikit jika bibandingkan tahun 2009 di Hirarki VI yang terdapat 3 kabupaten/kota. Jika dibandingkan pusat pertumbuhan ekonomi dengan perhitungan skalogram pada tahun 2009 dengan 2018 terdapat perbedaan, khusunya pada Hirarki I mengalami peningkatan. Selain itu, daerah yang terdapat pada Hirarki IV, V, dan VI pada tahun 2009 lebih banyak dari 2018 pada hirarki yang sama. Terjadinya perubahan hirarki tersebut dapat diartikan bahwa pusat pertumbuhan mengalami perubahan dari tahun 2009 ke tahun 2018.

Berdasarkan analisis skalogram ditemukan perubahan kelas pada daerah-daerah yang menjadi objek penelitian tahun 2009 dengan 2018. Provinsi Jawa Timur pada tahun 2018 menjadi lebih maju/berkembang dibandingkan pada tahun 2009. Perkembangan tersebut dapat dilihat dari banyaknya daerah-daerah yang menjadi pusat pertumbuhan baru. Sementara itu, jumlah daerah yang kurang berkembang/tertinggal, menjadi lebih sedikit. Mayoritas daerah yang tertinggal menjadi daerah menengah-berkembang. Daerah yang menjadi pusat pertumbuhan cenderung berkumpul terdapat pada bagian tengah-selatan dan timur Provinsi Jawa Timur. Hal ini sejalan dengan temuan dari penelitian Wibisono dan Kuncoro (2015), dimana daerah yang berada di hirarki yang sama berkumpul di satu kawasan. Selain itu, daerah-daerah yang menjadi pusat pertumbuhan memiliki infrastruktur yang lebih lengkap dibandingkan dengan daerah lainnya.

Funke dan Niebuhr (2005) menemukan pusat pertumbuhan di Jerman terdapat pada wilayah Jerman bagian timur yang mayoritas merupakan wilayah industry, dan wilayah ini mampu memberikan spillover effect ke daerah 
sekitarnya. Pada tahun 2018 pusat pertumbuhan di Provinsi Jawa Timur terdiri dari Kabuaten Malang, Kabupaten Sidoarjo, Kota Surabaya, Kabupaten Banyuwani, Kabupaten Kediri, Kabupaten Malang, Kabupaten Nganjuk, Kabupaten Jombang, dan Kabupaten Tulungagung. Salah satu faktor pendukung pusat pertumbuan ekonomi di sektor industri, diantaranya terdapat limbung pabrikasi kapal terbesar di Indonesia PT PAL di Surabaya, industri perlengkapan tempur PT Pindad di Malang, pabrik kertas (PT Tjiwi Kimia di Tarik-Sidoarjo) pabrik rokok (Sampoerna di Surabaya, serta Bentoel di Malang). Selain itu, pemerintah juga menetapkan 12 kawasan industri estate, di antaranya Surabaya Industrial Estate Rungkut (SIER) di Surabaya, Ngoro Industrial Park (NIP) di Kabupaten Mojokerto, Kawasan Industri Jabon di Kabupaten Sidoarjo. Sentra industri kecil tersebar di seluruh kabupaten/kota, dan beberapa di antaranya telah menembus ekspor; Industri kerajinan kulit berupa tas, dan sepatu di Tanggulangun, Sidoarjo adalah salah satu industri kecil yang sangat terkenal (Laporan Perekonomian Provinsi Jawa Timur, 2019).

Pada sektor pertambangan dan energi, Jawa Timur memiliki Blok Cepu, yang merupakan salah satu produsen minyak bumi terbesar di Indonesia dan tambang di Bojonegoro. Pembangkit listrik di Jawa Timur dikelola oleh PT PJB, dimana melingkupi PLTA, PLTU, dan PLTGU, yang memasok energi listrik ke sistem Jawa-Bali. (Laporan Perekonomian Provinsi Jawa Timur, 2019). Selain itu, juga keberadaan fasilitas rumah peribadatan menjadi penting, dikarenakan hanya beberapa daerah yang memiliki fasilitas rumah ibadah yang lengkap untuk memenuhi kebutuhan masyarakat. Dari 38 kabupaten/kota hanya 5 daerah yang memiliki fasilitas yang lengkap.

\section{Interaksi Spasial Pusat Pertumbuhan Ekonomi dengan Wilayah di Sekitarnya di Provinsi Jawa Timur}

Analisis gravitasi ialah alat analisis yang dikenakan agar dapat melihat interaksi suatu wilayah dengan wilayah lainnya melalui perbandingan antara jumlah penduduk dengan jarak antar wilayah. Hasil analisis gravitasi ini merupakan analisis dari daerah kabupaten/kota yang menjadi pusat pertumbuhan dari hasil analisis skalogram Provinsi Jawa Timur pada tahun 2009 dan 2018. Pada penelitian ini Kota Surabaya dijadikan sebagai pusat pertumbuhan untuk menganalisis nilai interaksi dengan kabupaten/kota di Provinsi Jawa Timur. Hal tersebut didasarkan pada perhitungan skalogram yang menunjukkan bahwa Kota Surabaya merupakan daerah dengan pusat pertumbuhan tertinggi di Provinsi Jawa Timur. Tabel 1 menunjukkan hasil perhitungan gravitasi Kota Surabaya dengan wilayah kabupaten/kota lainnya di Provinsi Jawa Timur pada tahun 2009. Tabel 1 menunjukkan pada tahun 2009 nilai interaksi spasial Kota Surabaya memiliki daya tarik terbesar pada Kabupaten Sidoarjo dan Kabupaten Gresik. Sementara itu kawasan yang memiliki daya tarik terkecil dengan Kota Surabaya adalah Kota Blitar dan Kota Madiun. Penelitian ini membandingkan dengan data tahun 2018 apakah terjadi perbedaan nilai interaksi kabupaten/kota di Provinsi Jawa Timur dengan Kota Surabaya sebagai pusat pertumbuhan. Tabel 2 yang menunjukkan hasil perhitungan gravitasi Kota Surabaya dengan wilayah kabupaten/kota lainnya di Provinsi Jawa Timur pada tahun 2018.

Tabel 1.

Hasil Analisis Gravitasi Wilayah Kota Surabaya dengan Kabupaten/Kota Lainnya Di Provinsi Jawa Timur Tahun 2009

\begin{tabular}{|c|c|c|}
\hline No & Kabupaten/Kota & Nilai Interaksi (Penduduk²/Km²) \\
\hline 1 & Kab. Sidoarjo & 206.269 .009 .557 \\
\hline 2 & Kab. Gresik & 177.704.275.225 \\
\hline 3 & Kab. Bangkalan & 91.503 .410 .691 \\
\hline 4 & Kab. Malang & 71.706 .091 .010 \\
\hline 5 & Kab. Lamongan & 69.562.076.228 \\
\hline 6 & Kab. Pasuruan & 63.706 .255 .319 \\
\hline 7 & Kab. Mojokerto & 54.452 .190 .282 \\
\hline 8 & Kab. Jombang & 43.349.292.907 \\
\hline 9 & Kab. Jember & 31.094 .769 .807 \\
\hline 10 & Kab. Kediri & 31.059.792.214 \\
\hline 11 & Kab. Bojonegoro & 30.964 .070 .024 \\
\hline 12 & Kab. Probolonggo & 30.530 .589 .222 \\
\hline 13 & Kab. Tuban & 27.615.277.384 \\
\hline 14 & Kab. Sampang & 26.885 .029 .220 \\
\hline 15 & Kota Malang & 22.736.442.810 \\
\hline 16 & Kab. Nganjuk & 22.168 .128 .702 \\
\hline 17 & Kab. Lumajang & 18.657.233.304 \\
\hline 18 & Kab. Pamekasan & 18.220 .280 .337 \\
\hline 19 & Kab. Tulungagung & 16.950 .814 .966 \\
\hline 20 & Kab. Blitar & 16.866 .575 .342 \\
\hline 21 & Kab. Sumenep & 15.294 .112 .905 \\
\hline 22 & Kab. Banyuwangi & 14.031 .134 .814 \\
\hline 23 & Kab. Ngawi & 12.164 .789 .201 \\
\hline 24 & Kab. Ponorogo & 11.948 .375 .606 \\
\hline
\end{tabular}


Irhas Fudhail, Herman Sambodo dan Sodik Dwi Purnomo, Identifikasi Pusat Pertumbuhan dan Analisis Interaksi Spasial Perekonomian di Provinsi Jawa Timur

\begin{tabular}{l|lr}
25 & Kab. Madiun & 10.005 .949 .712 \\
26 & Kab. Bondowoso & 9.766 .372 .627 \\
27 & Kab. Trengalek & 9.072 .317 .514 \\
28 & Kab. Magetan & 8.536 .099 .400 \\
29 & Kab. Situdondo & 8.475 .768 .241 \\
30 & Kota Pasuruan & 6.642 .175 .704 \\
31 & Kota Kediri & 5.831 .970 .110 \\
32 & Kota Mojokerto & 5.734 .673 .105 \\
33 & Kota Probolinggo & 5.721 .051 .381 \\
34 & Kab. Pacitan & 5.326 .043 .078 \\
35 & Kota Batu & 4.797 .254 .667 \\
36 & Kota Madiun & 2.878 .295 .780 \\
37 & Kota Blitar & 2.180 .392 .179 \\
\hline
\end{tabular}

Sumber: Data BPS diolah, 2020

Tabel 2.

Hasil Analisis Gravitasi Wilayah Kota Surabaya dengan Kabupaten/Kota Lainnya Di Provinsi Jawa Timur Tahun 2018

\begin{tabular}{|c|c|c|}
\hline No & Kabupaten & Nilai Interaksi (penduduk²/ $\mathrm{km}^{2}$ ) \\
\hline 1 & Kab. Sidoarjo & 278.117 .820 .270 \\
\hline 2 & Kab. Gresik & 208.244.733.240 \\
\hline 3 & Kab. Bangkalan & 100.880 .239 .466 \\
\hline 4 & Kab. Malang & 84.031 .090 .126 \\
\hline 5 & Kab. Pasuruan & 77.745 .412 .180 \\
\hline 6 & Kab. Lamongan & 76.237.196.705 \\
\hline 7 & Kab. Mojokerto & 65.291 .158 .541 \\
\hline 8 & Kab. Jombang & 45.972 .297 .000 \\
\hline 9 & Kab. Probolonggo & 37.258.670.901 \\
\hline 10 & Kab. Kediri & 36.787.612.258 \\
\hline 11 & Kab. Jember & 35.750 .327 .341 \\
\hline 12 & Kab. Bojonegoro & 33.315.522.588 \\
\hline 13 & Kab. Tuban & 32.729 .393 .580 \\
\hline 14 & Kab. Sampang & 31.052.419.207 \\
\hline 15 & Kota Malang & 26.307.696.058 \\
\hline 16 & Kab. Nganjuk & 25.506.851.298 \\
\hline 17 & Kab. Lumajang & 20.692 .295 .005 \\
\hline 18 & Kab. Pamekasan & 20.445 .142 .486 \\
\hline 19 & Kab. Blitar & 20.000.179.117 \\
\hline 20 & Kab. Tulungagung & 19.398.611.922 \\
\hline 21 & Kab. Sumenep & 17.894 .183 .977 \\
\hline 22 & Kab. Banyuwangi & 16.127 .817 .763 \\
\hline 23 & Kab. Ngawi & 13.233 .537 .845 \\
\hline 24 & Kab. Ponorogo & 12.689 .228 .113 \\
\hline 25 & Kab. Bondowoso & 11.667 .567 .905 \\
\hline 26 & Kab. Madiun & 11.634 .318 .720 \\
\hline 27 & Kab. Trengalek & 10.230 .499 .697 \\
\hline 28 & Kab. Situdondo & 10.114 .212 .377 \\
\hline 29 & Kab. Magetan & 9.403 .081 .828 \\
\hline 30 & Kota Pasuruan & 8.325 .369 .830 \\
\hline 31 & Kota Mojokerto & 7.118.553.202 \\
\hline 32 & Kota Kediri & 6.699 .695 .675 \\
\hline 33 & Kota Probolinggo & 6.402 .964 .878 \\
\hline 34 & Kab. Pacitan & 5.796 .139 .053 \\
\hline 35 & Kota Batu & 5.709 .736 .465 \\
\hline 36 & Kota Madiun & 3.108.956.779 \\
\hline 37 & Kota Blitar & 2.526 .581 .204 \\
\hline
\end{tabular}

Sumber: Data BPS diolah, 2020

Tabel 2 menunjukkan bahwa secara keseluruhan interaksi antar daerah pusat pertumbuhan dengan daerah hinterlandnya pada tahun 2009 ke 2018 mengalami kenaikan. Kenaikan ini interaksi ini disebabkan oleh bertambahnya jumlah penduduk dari tahun 2009 ke tahun 2018. Interaksi yang kuat antar wilayah pusat pertumbuhan dengan daerah sekitarnya juga membantu perkembangan daerah yang kurang maju. Dari tahun 2009 ke tahun 2018 daerah hinterland yang berinteraksi kuat dengan Kota Surabaya seperti Kabupaten Sidoarjo, Kabupaten Gresik dan 
Kabupaten Pasuruan berkembang menjadi daerah yang lebih maju, Kabupaten Sidoarjo yang sebelumnya tertinggal pada tahun 2009, pada tahun 2018 berkembang menjadi salah satu daerah pusat pertumbuhan baru. Hasil dari analisis gravitasi mengenakan Kota Surabaya sebagai salah satu daerah pusat pertumbuhan pada tahun 2009 dan 2018, memiliki interaksi terkuat dengan Kabupaten. Sidoarjo, Kabupaten Gresik dan Kabupaten Bangkalan. Namun dari segi nilai interaksi, dari tahun 2009 ke tahun 2018, nilai interaksi kesemua daerah meningkat. Hasil ini dipengaruhi oleh semakin bertambahnya jumlah penduduk. Provinsi Jawa Timur tahun 2018 menunjukkan bahwa ketimpangan pendapatan antar wilayah yang cukup tinggi. Namun berbanding terbalik dengan ketimpangan pendapatan antar penduduk yang menunjukkan ketimpangan pendapatan masyarakat termasuk merata secara umum. Hal tersebut dikarenakan terjadinya perpindahan penduduk antar wilayah yang bertujuan untuk bekerja dan mentransfer pendapatan ke wilayah asal, sehingga hal tersebut berdampak pada meratanya ketimpangan pendapatan didaerah asal. Sejalan dengan temuan Istiqomah et al (2020) yang menyatakan bahwa remitansi dari pekerja migran dapat menurunkan ketimpangan pendapatan didaerah asal

Selain itu keberadaan fasilitas jalan provinsi dan kabupaten yang cenderung baik (Bappeda Provinsi Jawa Timur, 2018) membuat masyarakat lebih sering lagi melakukan migrasi atau perpindahan dari daerah asal ke daerah tujuan. Di Kabupaten Sidoarjo memiliki imteraksi yang tinggi dengan Kota Surabaya dikarenakan Kabupaten sidoarjo mempunyai potensi ekonomi yang cukup kuat dan akan terus berkembang. Hal ini karena adanya dorongan relokasi industri dari Surabaya ke Sidoarjo. Selain itu, tingginya mobilitas dan meningkatnya pertumbuhan penduduk juga menyebabkan potensi meningkatnya permintaan masyarakat dalam bidang properti (Kinerja Perekonomian Kabupaten Sidoarjo, 2018). Sama halnya dengan Kabupaten Bangkalan yang memiliki interaksi spasial yang tinggi dengan kota Surabaya dikarenakan adanya kemudahan akses mobilitas barang dan jasa karena didukung dengan infrastruktur jalan berupa Jembatan Suramadu. Selain itu, didukung dengan kebijakan pemerintah pusat mengenai penghapusan biaya tiket kendaraan yang melintasi jembatan tersebut berdampak pada meningkatnya mobilitas penduduk dari Kabupaten Bangkalan ke Kota Surabaya dan sebaliknya. Wang (2017) berpendapat perpindahan atau mobilitas penduduk terjadi karena adanya hubungan supply-demand antar daerah berupa ketersediaan barang/jasa. Wang juga berpendapat daerah yang dituju biasanya terdapat fasilitas yang lengkap baik berupa infrastruktur, informasi maupun sumber daya lainnya yang tidak dimiliki daerah asal. Jarak, kemudahan akses dan biaya perjalanan juga mempengaruhi mobilitas (pendapat Wang semua). Temuan Ke dan Feser (2010) di Cina kota-kota besar/pusat pertumbuhan memberikan spillover effect kepada daerah sekitarnya, efek limpahan ini bisa diperkuat dengan adanya kelengkapan fasilitas penunjang perjalan seperti; jalur kereta api, tol dan lain sebagainya. Selain itu Funke \& Niebuhr (2005) dalam penelitiannya di Jerman spillover effect akan semakin melemah ketika jarak antar wilayah semakin jauh. Temuan Mustatea (2013) menjelaskan bahwa perkembangan wilayah di Negara Rumania dipengaruhi oleh pertumbuhan kota-kota yang merupkan pisatpusat pertumbuhan di negara tersebut.Jika dilihat lebih lanjut 3 daerah yang menjadi pusat pertubuhan pada tahun 2009 memberikan spread effect, sehingga mampu mengangkat daerah sekitarnya menjadi lebih berkembang bahkan menjadi pusat pertumbuhan baru pada tahun 2018. Temuan yang sama juga terdapat dalam penelitian yang dilakukan oleh Pratiwi dan Kuncoro (2016), dimana spread effect terjadi saat daerah yang berada di sekitar wilayah pusat pertumbuhan (wilayah hinterland) menjadi lebih maju atau berkembang.

\section{Simpulan}

Hasil analisis skalogram dan indeks sentralitas Provinsi Jawa Timur pada tahun 2009 dan 2018, menghasilkan 6 hierarki daerah berdasarkan keberadaan jenis fasilitas di setiap wilayah kabupaten/kota. Pada tahun 2009 terdapat 3 kabupaten/kota yag termasuk dalam Hirarki I, 5 kabupaten/kota pada Hirarki II, 6 kabupaten/kota pada Hirarki III, 9 kabupaten/kota pada Hirarki IV, 12 kabupaten/kota pada Hirarki V dan 3 kabupaten/kota VI. Pada tahun 2018 terdapat 8 kabupaten/kota pada Hirarki I, 10 kabupaten/kota pada Hirarki II, 11 kabupaten/kota pada Hirarki III, 4 kabupaten/kota pada Hirarki IV, 3 kabupaten/kota pada Hirarki V dan 2 kabupaten/kota pada Hirarki VI. Pusat pertumbuhan dengan daerah hinterlandnya pada tahun 2009 ke 2018 mengalami kenaikan. Dari tahun 2009 ke tahun 2018 daerah hinterland yang berinteraksi kuat dengan Kota Surabaya seperti Kabupaten Sidoarjo, Kabupaten Gresik dan Kabupaten Bangkalan. Temuan ini mengimplikasikan 1) perlunya peningkatan kerja sama antar wilayah baik dalam bidang ekonomi maupun sosial antara wilayah yang menjadi pusat pertumbuhan dengan wilayah hinterlandnya seperti dalam bidang ekonomi yaitu dengan memakai produk barang dan jasa dalam membantu pertumbuhan ekonomi di masing-masing wilayah., dan 2) untuk mendorong mobilitas penduduk ke daerah lainya perlunya infrastruktur jalan yang baik dan moda transportasi yang memadai. Selain iu, memprioritaskan pembangunan sektor yang dianggap memiliki daya saing dan berdampak positif terhadap sektor pendukungnya.

\section{Daftar Pustaka}

Adisasmita, R. (2013). Teori-Teori Pembangunan Ekonomi. Yogyakata: Graha Ilmu.

Badan Pusat Statitik Provinsi Jawa Timur. (2020). Provinsi Jawa Timur dalam Angka 2010-2019. Surabaya.

Budiharsono, S. (2001). Teknik analisis pembangunan wilayah pesisir dan lautan. Jakarta: Pradnya Paramita. 
Irhas Fudhail, Herman Sambodo dan Sodik Dwi Purnomo, Identifikasi Pusat Pertumbuhan dan Analisis Interaksi Spasial Perekonomian di Provinsi Jawa Timur

Capello, R. (2009). Spatial Spillovers and Regional Growth: A Cognitive Approach. European Planning Studies, 17(5), 639-658.

Dobrescu, E. M., \& Dobre, E. M. (2014). Growth Poles. Related Concepts. Knowledge Horizons - Economics, 6(2), $17-20$.

Funke, M., \& Niebuhr, A. (2005). Regional Geographic Research and Development Spillovers and Economic Growth: Evidence from West Germany. Regional Studies, 39 (1), 143-153. https://doi.org/10.1080/0034340052000321904

Hakim, A. (2009). Ekonomi Pembangunan. Yogyakarta: Ekonesia.

Istiqomah, I., Purnomo, S. D,. Rahmawati, G. P., \& Rahmawan, P. G. (2020). Does Migration Outflow Reduce Income Inequality in the Sending Province?. Economics Development Analysis Journal 9 (2): 159-168. https://doi.org/10.15294/edaj.v9i2.38430

Irsyad, M., \& Syahnur, S. (2018). Interaksi Spasial Ekonomi Indonesia. Jurnal Ilmiah Mahasiswa Ekonomi Pembangunan, 3(4): 475-483.

Ke, S., \& Feser, E. (2010) Count on the Growth Pole Strategy for Regional Economic Growth? Spread-Backwash Effects in Greater Central China, Regional Studies, 44 (9) :1131-1147, http://dx.doi.org/10.1080/00343400903373601

Kubis, A., Titze, M., \& Ragnitz, J. (2007). Spillover Effects of Spatial Growth Poles - a Reconciliation of Conflicting Policy Target?. IWH-Discussion Papers Nr. 8/2007. Germany: Institut fur Wirtschaftsforschung Halle - IWH.

Kuncoro, M. (2012). Ekonomika Aglomerasi, Dinamika dan Dimensi Spasial Kluster Industri Indonesia. Yogyakarta: UPP STIM YKPM.

Mulyadi, M. (2007). Sistem Perencanaan dan Pengendalian Manajemen. Jakarta: Salemba Empat.

Mustatea, N, M. (2013). Growth Poles - An Alternative to Reduce Regional Disparities. Case Study - Iaşi Growth Pole. Romanian Review of Regional Studies, 9(1): 51-60.

Mutaali, L. L. (2003). Studi Penentuan Desa-Desa Pusat Pertumbuhan di Provinsi DIY. Majalah Geografi Indonesia, 17(1): 33-51.

Pratiwi, M. C. Y., \& Kuncoro, M. 2016. Analisis Pusat Pertumbuhan dan Autokorelasi Spasial di Kalimantan: Studi Empiris di 5 Kabupaten/ Kota, 2000-2012. Jurnal Ekonomi dan Pembangunan Indonesia, 16 (2): 81-104. https://doi.org/10.21002/jepi.v16i2.574

Priyadi, U., \& Atmadji, E. (2017). Identifikasi Pusat Pertumbuhan dan Wilayah Hinterland di Provinsi Daerah Istimewa Yogyakarta, Asian Journal of Inovation and Enterpreneurship, 2(2): 193-219.

Riyadi, S. (2008). Perencanaan Pembangunan Daerah Strategi Menggali Potensi dalam Mewujudkan Otonomi Daerah. Jakarta: PT. Gramedia Pustaka Utama.

Rondinelli, D A. (1985). Planning Development Project. Boston: Little Brown and Company.

Sjafrizal, S. (2008). Ekonomi Regional Teori dan Terapan. Padang: Baduose Media.

Sukirno, S. (2001). Pengantar Teori Makroekonomi. Jakarta: PT. Raja Grafindo Persada.

Tarigan, R. (2006). Ekonomi Regional Teori dan Aplikasi. Jakarta: Bumi Aksara.

Wang, J. (2017). Economic Geography: Spatial Interaction. International Encyclopedia of Geography: People, the Earth, Environment and Technology, 1-4. https://doi.org/10.1002/9781118786352.wbieg0641

Wibisono, P., \& Kuncoro, M. (2015). Efek Limpahan Perumbuhan Antar-Kabupaten/Kota di Provinsi Jawa Timur Tahun 2001-2013. Jurnal Ekonomi dan Pembangunan Indonesia 16(1): 31-46. https://doi.org/10.21002/jepi.v16i1.584 